INDEPENDENT JOURNAL OF MANAGEMENT \& PRODUCTION (IJM\&P)

\title{
GREEN ECONOMY AND THE REVERSE LOGISTICS OF WASTE ELECTRICAL AND ELECTRONIC EQUIPMENT IN THE WORLD
}

\author{
Marcus Vinicius Faria de Araujo \\ Sao Paulo State University, Brazil \\ E-mail: marcusvinicius@vwa.com.br \\ Fernando Augusto Silva Marins \\ Sao Paulo State University, Brazil \\ E-mail: fmarins@feg.unesp.br
}

Submission: $19 / 08 / 2015$

Revision: 31/08/2015

\section{ABSTRACT}

Accept: 15/09/2015

The way globally accepted for the representation of economic growth, and the evolution of a country, does not take into accounts the environmental assets and liabilities. This article suggests a shift this paradigm by implementing green economy concept and environmental goals to achieve an appropriate level in terms of pollution at a lower cost to society. The focus of the study is given to the management of waste electrical and electronic equipment (WEEE), particularly in the reverse logistics of WEEE as a potential tool for economic growth maintenance condition with sustainability. A diagnosis on the use of reverse logistics of WEEE in the world is also presented based on research conducted in countries on five continents. At the end of the study it was concluded that the application of reverse logistics in the world is still incipient with no evidence of the use of economic instruments that give opportunity for growth and sustainability. Accordingly, it is emphasized that the management of WEEE practiced in most countries has shown motivation solely on financial profit based on the export/import of waste in a kind of ruse coated green taking into account the environmental and health risks of the population in developing or in 
development countries, which are the main final destination of WEEE.

Keywords: Reverse logistics; Green Economy; Electronics Waste; Economic Instruments; Sustainability.

\section{INTRODUCTION}

Although the growth models and development historically used by nations consider the economic process as a cycle involving production and consumption (HEUTEL; FISCHER, 2013), it is necessary to realize that it cannot be considered a closed, mechanistic cycle; but dependent on factors such as environmental conservation and preservation, is including in this regard the social and cultural context, because human beings are part of the environment (AZIZ et al., 2015).

Jackson (2003) suggests that the maintaining economic growth must lead to the admission that we live a crisis of perception when not inserted and practice the use of environmental assets and liabilities in the calculations that measure the occupation of economics, translated by the Gross Domestic Product (GDP).

Facing this scenario, this paper presents a diagnosis of the WEEE management in countries across five continents identifying integration opportunities of real aspects of sustainability as a contribution to economic growth through conservation and environmental preservation actions. Therefore, it is suggested, as a first approximation, the application of reverse logistics and waste management tool for electronic equipment (WEEE).

The relevance of this proposal lies in the fact that reverse logistics has the potential to achieve environmental goals at a lower cost to society since it benefits from economies of scale. Thereby reverse logistics becomes a virtual tool for the practice of a Green Economy, which has the strong contribution to growth and development from a systemic view and high entropy, with respect to greater diversity in the composition of inducing tools of economic growth.

From the aforementioned proposal follows a verification of WEEE management forms in countries on five continents under certain characteristics described throughout the work. Finally it is concluded that except for a few countries in the European continent the practice of reverse logistics has been little or almost completely disregarded in the WEEE management in the world. Although there is a 
DOI: 10.14807/ijmp.v7i1.362

world market established for recycling of WEEE, it is noticed that often the banner of sustainability has been used to cover only practices to revenue, and export / import of environmental problems.

This paper is organized as follows. The second section is a discussion of the model of economic growth with their interactions in relation to the consumption of natural resources. The third section is an approach on the implementation of reverse logistics of WEEE as contribution tool to establish a green economy has the potential to induce economic growth. The fourth section includes the status quo of reverse logistics in five continents from the study of the practices of leading countries from every continent due to characteristics related to occupation of the economy of each of these clusters. The fifth section presents the conclusions of the work followed by the last section containing the references.

\section{ECONOMIC GROWTH AND STOCKS OF NATURAL RESOURCES}

Friedman (2006) from exhaustively reviewed in the trajectory of economic growth in the world says that social stability would be a corollary of the need for infinite growth. Bouder (2008) and Rutherford (2008) suggest that economic growth be rooted in innovation processes and not just in cost savings.

Furthermore, it is essential to consider the irresistible impetus for consumption at facilities and to have things in a kind of extended self, as stated Ahuvia (2005) and Hamilton (2010). Such consumer goods and services whether from government or people's expenses is part of the economic variable known as Gross Domestic Product (GDP), which measures the occupation of the economy, in this case, through the demand (or willingness to spend/invest) aggregated. Such expenditures imply an earlier generation of income, which, along with the production, form aggregated supplies (willingness to sell). Costa, Silva and Lima (2014) highlight the relationship between GDP and economic growth.

Jackson (2009), however, proposes a change in the government accounts system in GDP in order to also incorporate the environmental assets and liabilities when considering the continuing need for economic growth. Such a change in the government system of accounts is justified by the existence of market failure in that processes are not $100 \%$ efficient, nor $100 \%$ effective (BERKEL, 2007), generating residual emissions to the environment which increase the extent that the 
INDEPENDENT JOURNAL OF MANAGEMENT \& PRODUCTION (IJM\&P)

http://www.ijmp.jor.br

v. 7, n. 1, January - March 2016

ISSN: 2236-269X

DOI: 10.14807/ijmp.v7i1.362

consumption increases in a vicious cycle generator external environmental factors as shown in Figure 1.

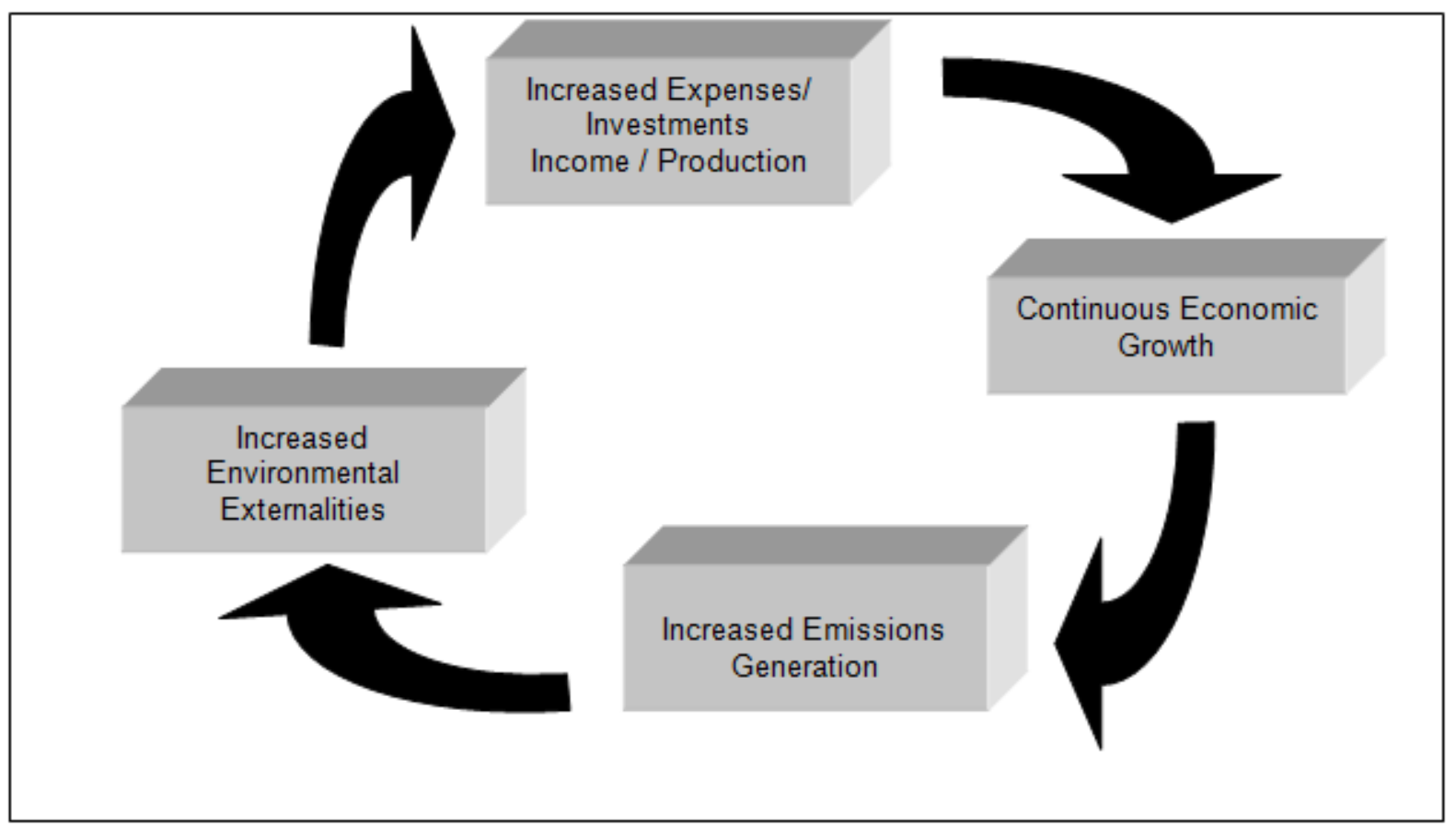

Figure 1: Vicious cycle generated by society.

The transformation of the vicious cycle proposed in Figure 1 in a virtuous cycle maintaining the occupation of the economy; i.e. keeping the idea of permanent economic growth, implies the pricing of environmental externalities (ORSATO, 2009; PERERA et al., 2013). Considering the relationship between capital (K) and natural resources $(R)$, the non-exhaustion of natural resources depends on two conditions (PALMER, 2012; HOCHSTETLER, 2002):

1st) When the stock of natural resources is zero, production must be zero:

$$
F(K, 0)-0
$$

2nd) When the use of natural resources in production tends to zero, marginal productivity tends to infinity:

$$
\lim _{R \rightarrow 0} \frac{d F\left(K_{v} R\right)}{d R}=\infty
$$

Thus, pricing of environmental externalities is not looking for the end of the exploitation of natural resources, but confirms the indispensability of natural resources to the status of great economic growth providing opportunities to strengthen the green economy (UNEP, 2011). 


\section{THE REVERSE LOGISTICS OF ELECTRONICS WASTE AS THE GREEN ECONOMY TOOL}

Assuming a low trade-off between economic growth and natural resources, new economic stimulus strategies have gradually been emerging and reaching influence directly or indirectly in the design of products as stated Rowley et al. (2012). The United Nations Environment Programme defines green economy as an economic model that brings together the scope of social welfare, in a fair and efficient use of natural resources (UNEP, 2011).

Kirkland (2014) suggests that the green economy moves to be a tutor of economic growth in the world relying on three main pillars of support: use of economic instruments (pigouvian taxes and pollution markets); improvements in environmental laws and public investments in conservation/environmental preservation.

The Reverse Logistics that, according to Hazen, Hall and Hanna (2012), brings together the aspect of innovation in the supply chain, emerges as a facilitator instrument of the green economy implementation, as it presupposes the bias of sustainability in business strategies (PRZYCHODZEN; PRZYCHODZEN, 2013) accompanied by changes in environmental legislation, reduction of use of command and control instruments, introduction of economic instruments in the management of the environment and incentives, to a greater or lesser extent, by government.

In light of the potential for transactions of waste electrical and electronic equipment (WEEE) because they have in their constitution some components of high economic value (DWIVEDY; MITTAL, 2015), is very promising the possibility of WEEE reverse logistics occupy a prominent place in global green economy.

\section{DIAGNOSTIC OF THE APPLICATION OF REVERSE LOGISTICS IN THE WORLD}

Ratifying what was mentioned in the previous section, there has been the increasing use of WEEE Reverse Logistics as a tool for sustainable occupation of the economy in the whole world, and in the sequence are highlighted some countries and their strategies related to that. 


\subsection{WEEE Reverse Logistics in the Americas}

In the Americas, are highlighted the United States (US), that are the leader of the worldwide generation of WEEE (HUISMAN, 2012), and Brazil that generates, in absolute numbers, the greatest amount of WEEE among emerging countries according to UNEP (2011).

\subsubsection{United States}

In the USA the WEEE is not considered hazardous waste, a fact that, according to Wagner (2009), explains the absence of a policy at the federal level for such waste. Lepawsky (2012) indicates that not all states of the country have specific legislation, and that, by 2010, 24 states were counted with legislation on WEEE management considering to blame the consumer electronics producers of "cradle to grave" by waste generated after consumption.

Townsend (2011) points to the lack of uniformity of laws in the states of that country, existing from rates to the consumer (the system used in California) embedded in the final price of the new product and form a fund managed by the state for future collection and recycling - until the imposition of WEEE collection and recycling costs borne by the retailers.

The asymmetry of legislation on WEEE management induces consumers to seek a situation of lower cost in the post consumption stage, which can make them have direct contact with hazardous components of WEEE causing health damage thereof (WAGNER, 2009). Between 2000 and 2011, the percentage of WEEE recycling in the US rose from $10 \%$ to $24.9 \%$ showing improvement in the management of such waste but still lacking a proportionate boost to the fact that the US is the largest WEEE generators on the planet Kyle (2013).

\subsubsection{Brazil}

Unlike what happens in the US, Brazil has a national policy for solid waste management where obviously WEEE is contemplated. However, such policy, even though it was proposed in the form of draft law in 1991, only in 2010 was its regulation.

Law 12,305/2010 becomes the regulatory framework in Brazil on solid waste management giving meaning and managerial viability because of its interface with Law 9.795/1999 (National Environmental Education Policy - PNEA, acronym in 
DOI: 10.14807/ijmp.v7i1.362

Portuguese) and the Law 11,445/2007 (National Basic Sanitation Policy - PNSB, acronym in Portuguese).

There is also an important integration with the Brazilian Environmental Licensing System that is regulated by the National Council of Environment (CONAMA, acronym in Portuguese), Law 237/1997, and by Complementary Law 140/2011 establishing the need for cooperation and division of powers between the federal, state and municipal levels. About the WEEEs, in Brazil it becomes mandatory the practice of reverse logistics operations, and the producers are responsible for collecting and recycling originated from post consumption of its products.

Demajorovic and Migliano (2013), however, punctuate that after four years of regulation of Law 12,305/2010, the implementation of reverse logistics in Brazil to WEEE practically has not occurred yet. The same authors attribute this fact to the lack of political acceptability of electronic producers and other stakeholders, lack of tax incentives and difficulties regarding the aspect of administrative feasibility.

Considering, in particular, the aspect of administrative feasibility is important to note that the slowness in implementing reverse logistics for WEEE in Brazil can be explained, at least partly, by the complexity of the Brazilian environmental licensing system requiring electronics manufacturers to hire or possess additional environmental licenses. This is the fact that an environmental license for the production and transportation of electronic products is not valid for the collection and transport of WEEE.

Similarly, to the extent that such manufacturers become WEEE receptors, their environmental licenses have to be at least legally registered, because not only they have their activities in order to produce consumer electronics, but also to recycle them. These difficulties have a direct impact on the costs and benefits of electronics producers in Brazil leading to insecurities regarding the competitiveness and business success in the industry, as suggested by Hernández, Marins and Castro (2010), besides highlighting the lack of use of reverse logistics as a tool for strengthening Green Economy. 
DOI: 10.14807/ijmp.v7i1.362

\subsection{WEEE Reverse Logistics in the African Continent}

Reverse logistics of WEEE and even from other waste on the African continent, as Marchi (2011), is not yet a reality, either as part of any environmental policy, whether in terms of legislation or even any practice in the area. Despite the existence of Environmental Policy formalized in some countries like South Africa and Ghana, the main concern of those countries is even greater in dealing with WEEE imported from those produced on that continent (AMOYAW-OSEI, 2011).

The issue of importing WEEE from the other continents is part, in a similar context, of the anthropogenic cynicism (OELSCHLAEGER, 2014) given the existence of the Basel Convention which deals with the regulation of cross-border traffic of hazardous waste In contrast to the desire for countries that generate WEEE in take advantage of poverty of others to reduce their own costs, not just exporting WEEE but indirectly, diseases and their treatment costs of these diseases.

\subsection{WEEE reverse logistics in the Asian Continent}

In Asia it stands out here China by the fact of occupying, according to UNEP (2015), the second position in the global generation of WEEE, and India by the growing potential of WEEE generation due to strong rates of electronics industry growth that country (HERAT; AGAMUTHU; 2012).

\subsubsection{China}

The starting point of reverse logistics application of the concept of WEEE in China took place in 2009 from the government's actions in this country in order to create formal market of WEEE return to their respective manufacturers. Through economic incentives, consumers taking their electronics used in stores receive $10 \%$ discount on the purchase of new appliances (ONGONDO; WILLIAMS; CHERRET, 2011).

Qu et al. (2013) reported the existence of an alternative form of management of WEEE being the same carried through municipal collection and recycling programs. In this case Chinese municipalities have central receiving and WEEE recycling not setting the concept of extended responsibility present in countries like USA and Brazil.

Wang et al. (2013) highlight the absence of a government agency of management of WEEE as responsible for the prevalence of informality in WEEE 
DOI: 10.14807/ijmp.v7i1.362

recycling in China and also in charge of the private sector by isolated initiatives regulated by established practices in corporate environmental policies of companies like Nokia, LG, Lenovo and Motorola. Such informality turns out to corroborate the import of WEEE to China evidencing the large gap between economic growth and green economy in that country.

\subsubsection{India}

Similarly to China, India has an informal market of WEEE formed by collectors, dealers and recyclers (DWIVEDY; MITTAL, 2015). The practice of reverse logistics in the country is quite incipient giving ample room for amateur recycling techniques and therefore with high potential for direct and indirect environmental contamination.

Manhart (2010) states that the recycling techniques employed in India have relevant constituents' recovery efficiency of lower economic value to $20 \%$. The same author cites the use of products based cyanide leaching for the printed circuit boards in order to extract gold as high-risk practice for human health and air pollution, water and soil. Dwivedy and Mittal (2015) indicate that about $70 \%$ of WEEE from computers is marketed informally and the second hand market and the remainder (30\%) sold to recycling companies.

It is noteworthy that in India there are some companies authorized by the government to develop the process of collection, transportation and partial recycling of WEEE exporting crushed components containing heavy metals to Belgium (EPARISARAA PRIVATE LIMITED, 2015). Also according Dwivedy and Mittal (2015) exists in India the practice of WEEE import helping to create mismatched economic growth sustainability.

\subsection{WEEE reverse logistics on the European continent}

On the European continent were selected countries like Germany, Switzerland and the Nordic countries due to the uniqueness in responsible waste management in general and WEEE, respectively.

\subsubsection{Germany}

The formalization of a policy for solid waste took place in Germany in 1986, with the Law of Minimization and Waste Disposal (GERSTMAYR et al., 2011), and from this law, specific regulations have emerged in the country for the responsible 
DOI: 10.14807/ijmp.v7i1.362

management of used oils (1987), organic solvents (1989), containers and packaging in general (1991).

In 1994 arises the issue of the Law of Integral Cycle Economy and Waste, which replaced the Act of 1986 and expanded this being focused on non-generation of waste, reduction and recycling of the same. In parallel, there is the establishment, by the government, of the doctrine of consumer products with less waste and therefore less likely to cause significant environmental impacts. Therefore, reference is to the reverse logistics practice all-inclusive as manufacturers and distributors of products - including electronics - have responsibility over their entire life cycle.

There is also the forecast of development of waste management plans by the competent authorities (government and private) and that they should minimally contain the characterization of waste and the handling, transport and environmentally sound disposal. German law also determines a waste movement tracking system to be contained to the same specification, quantity, generator data, the carrier and the recipient thereof, including in transactions involving reverse logistics.

Such reverse logistics occurs in this country in centralized management and nonprofit inspired by the cooperation between manufacturers and distributors. Such an organization called "Duales System Deutschland GmbH - DSD" performs the reverse logistics being maintained through membership fees, by its members (GERSTMAYR et al., 2011).

\subsubsection{Switzerland}

Switzerland, in terms of solid waste management is considered a market benchmark since the market is $100 \%$ formal, articulated and regulated, particularly for reverse chain of WEEE (LIFSET; LINDHQVIST, 2008). Khetriwal, Kraeuchi and Widmer (2009) state that the reverse logistics in Switzerland began with the good practices of electronics producers in a kind of voluntary work for the preservation of the environment. It was precisely in this scenario that the government formalized what was already practice.

As occurs in some US states already mentioned above, in Switzerland, in all its territory, consumers pay a rate that is embedded in the price of electronic products allocated to finance in part the reverse logistics. Another strong point of reverse logistics in Switzerland is the aspect of cooperation between state, civil society and 
DOI: 10.14807/ijmp.v7i1.362

research centers; and such cooperation through Swiss research centers, reaches even interact with other nations like the US and India, sharing his expertise in the management of WEEE.

\subsubsection{Nordic Countries}

Among the Nordic countries, it is worthy to highlight Sweden, Denmark and Norway, for working with the concept of Extended Producer Responsibility (REP), as claimed Lifset and Lindhqvist (2008). This concept emphasizes a strategy focused on cleaner production where electrical and electronic products exert lower environmental impacts at all stages of their life cycle including removing the burden of WEEE management is of citizens, whether governments, in direct application of the polluter pays as cited by the European Commission (2011). The incidence in these countries of WEEE management costs on producers and importers gives opportunity to innovation in the development of electronic products.

\subsection{WEEE Reverse Logistics in the Oceania Continent}

On the continent of Oceania, it was selected Australia and New Zealand for being the countries with the highest Gross Domestic Product (GDP) according to Index Mundi (2015) and this fact, for such results, makes their respective economies generate larger amounts of WEEE that continent.

\subsubsection{Australia}

Australia until 2012 did not have regulations for the management of WEEE and according to Dave and Dave (2013) and Yousefpour, Barraket and Furneaux (2012), of the 25,000 tonnes of WEEE generated at the time, only $10 \%$ were recycled and the remainder is exported or disposed landfills.

It is emphasized that in this country there is the ever-increasing practice of WEEE export for the recovery of metals due to the high cost of direct labor for recycling WEEE. For lack of a formalized government policy there are two main routes used in WEEE management in Australia.

The first is sending, by consumers, the landfill through waste collection system. The duplicate is sending, from consumers and merchants, WEEE to the recyclers. By 2010, there were 14 WEEE recycling operating stations in Australia, 
DOI: 10.14807/ijmp.v7i1.362

which are responsible for recycling or trade in the form of export of WEEE to other countries.

According to Yousefpour, Barraket and Furneaux (2012) there is no evidence that such export operations comply with the provisions of the Basel Convention. Thereby the WEEE management in Australia, as suggested by Przychodzen and Przychodzen (2013), does not have the bias of sustainability and not a formal, unified system that can contribute to the achievement of environmental goals at a lower cost to society.

\subsubsection{New Zealand}

The first evidence of government action from New Zealand towards sustainability is the Resource Management Act validated in 1991. This law formalized the determination of the government of that country for the management of natural resources, but only in 2002, New Zealand started working a strategy for solid waste management. However, Clough (2012) indicates that, similar to what happens in Australia, costs of recycling and disposal in this country are high making it more attractive to export WEEE practice for countries like India.

There are also records of implementing the concept of post-consumer where local councils try, still little integrated, to create minimum conditions of scale to reduce contamination of the local environment and enable an increase for WEEE for sale. Thus, the experience of New Zealand with reverse logistics processes is virtually nonexistent not using the same as a tool that provides an opportunity for economic growth.

\section{CONCLUSION}

Even considering the good practices, intramural, of European countries, the reality of the WEEE management in the world has relied heavily on imports and exports of the same, excluding the socio-environmental damage caused by the countries that are predominantly receptors of these waste.

From this diagnosis, it is concluded that for the establishment of a Green Economy, inducing growth and economic development, it is necessary a paradigm shift with the inclusion of environmental assets and liabilities in determining the GDP of the countries and their consequent pricing. 
DOI: 10.14807/ijmp.v7i1.362

The potential negotiations revealed through the economic value of WEEE constituents, provides conditions for the practice of WEEE reverse logistics as a contribution instrument for a Green Economy internalizing external costs and reducing socio-environmental damage.

Finally, it is suggested, as a continuation of this research, using concepts from Game Theory, the possibility of performing an assessment of potential effects of inclusion of alternative strategic decisions related to WEEE reverse logistics in Brazil.

\section{REFERENCES}

AARON C. A. (2005) Beyond the Extended Self: Loved Objects and Consumers Identity Narratives. Journal of Consumer Research, v. 32, n. 1, p.171-184.

AMOYAW-OSEI, Y. et al. (2011) Ghana e-waste country assessment. SBC ewaste Africa project, 1ed. Dubendorf: EMPA.

AZIZ, N. A. A. et al. (2015) A Review on Green Integration into Management Control System. Procedia-Social and Behavioral Sciences, v. 172, n. 1, p. 435-441.

BERKEL, R. V. (2007) Cleaner production and eco-efficiency initiatives in Western Australia 1996-2004. Journal of Cleaner Production. v. 15, n. 8-9, p. 741-755.

BOUDER, F. (2008) Can decoupling work? Think-piece contributed to the SDC Workshop Economy Lite - can decoupling work? London: Sustainable Development Commission. Available: www.sd-commission.org.uk/. Acess: 05th May, 2015.

Clough, P. (2012) Building a Recycling Society: The Experience of New Zealand, in: Zhang, Y.; Kimura F.; Oum S. (Ed.), Moving Toward a New Development Model for East Asia- The Role of Domestic Policy and Regional Cooperation. Jakarta: ERIA, p. 393-428.

COSTA, R. F. R.; SILVA, D. O.; LIMA, F. S. (2014) Política Fiscal Local e Taxa de Crescimento Econômico: Um Estudo com Dados em Painel. Planejamento e Políticas Públicas, v. 42, n. 1, p. 11-38, $2013 .$.

DAVE, M.; DAVE, M. (2013) Green Computing: A Sustainable Bond between Energy, Environment and IT Industry. Journal of Development Management, v. 1, n. 3, p. 281.

DEMAJOROVIC, J.; MIGLIANO, J. E. B. (2013) Política nacional de resíduos sólidos e suas implicações na cadeia da logística reversa de microcomputadores no Brasil. Gestão \& Regionalidade, v. 29, n. 87, p. 64-80.

DWIVEDY, M.; SUCHDE, P.; MITTAL, R. K. (2015) Modeling and assessment of ewaste take-back strategies in India. Resources, Conservation and Recycling, $v$. 96, n.1, p. 11-18.

EC/EU European Comission ETC/SCP e EEA Environmental European Agency. Working. (2011) Key messages on material resource use and efficiency in 
Europe: Insights from environmentally extended input-output analysis and material flow accounts, 3 ed. Copenhagen.

E-PARISARAA PRIVATE LIMITED. Electronic Waste Recycling. Available: http://www.ewasteindia.com/. Acess: 02nd May, 2015.

FRIEDMAN, B. et al. (2013) Value sensitive design and information systems, in: SCHUURBIERS, D., VAN DE POEL, I., \& GORMAN, M. E. (Ed.), Early engagement and new technologies: Opening up the laboratory. Netherlands: Springer, p. 5595.

GERSTMAYR, B. et al. (2011) 3Rs Studie. Report to Federal Ministry for the Environment, Nature Conservation and Reactor Safety of German. 1ed. Augsburg: Bifa Environmental Institute.

HAMILTON, C. (2010) Consumerism, self-creation and prospects for a new ecological consciousness. Journal of Cleaner Production, v.18, n. 6, p. 571-575.

HAZEN, B.T.; HALL, D. J.; HANNA, J. B. (2012) Reverse Logistics Disposition Decision-Making: Developing a Decision Framework via Content Analysis.

International Journal of Physical Distribution \& Logistics Management, v. $42 \mathrm{n}$. 06, p. 244-274.

HERAT, S.; AGAMUTHU, P. (2012) E-waste: a problem or an opportunity? Review of issues, challenges and solutions in Asian countries. Waste Management \& Research, v. 30, n. 11, p. 1113-1129.

HERNÁNDEZ, C. T.; MARINS, F. A. S.; CASTRO, R. C. (2010) Modelo de gerenciamento da logística reversa integrado às questões estratégicas das organizações. Revista P\&D em Engenharia de Produção V, v. 8, n. 1, p. 16-20.

HEUTEL, G.; FISCHER, C. (2013) Environmental macroeconomics:

Environmental policy, business cycles, and directed technical change, $3 \mathrm{~d}$. Cambridge, MA: National Bureau of Economic Research.

HOCHSTETLER, R. L. (2002) Recursos naturais e o mercado: três ensaios (PhD. Dissertation in Economy). São Paulo: FEA/USP, Available:

http://www.race.nuca.ie.ufrj.br/teses/usp/Hochstetler.pdf. Acess: 06/05/2015.

HUISMAN, J. (2010) WEEE recast: from $4 \mathrm{~kg}$ to $65 \%$ : the compliance consequences. UNU Expert opinion on the EU WEEE Directive, v.1, n.1, p. 1-22. Available: http://www.researchgate.net/publication/236838730_WEEE_recast_from_4kg_to_65 the_compliance_consequences. Acess: 20th April, 2015.

INDEX MUNDI. Comparative map of Gross Domestic Product (GDP) between countries. Available: http://www.indexmundi.com/map/?v=65\&r=oc\&l=pt. Acess: 03rd May, 2015.

JACKSON, T. (2003) Sustainability and the struggle for existence. The critical role of metaphor in society's metabolism Environmental Values, v. 12, n. 3, p. 289316.

JACKSON, T. (2009) Prosperity without growth? The transition to a sustainable economy, 1 ed. St. Andrews: Sustainable Development Commission.

KHETRIWAL, D. S.; KRAEUCHI, P.; WIDMER, R. (2009) Producer responsibility for e-waste management: key issues for consideration-learning from the Swiss experience. Journal of Environmental Management, v. 90, n. 1, p. 153-165. 
KIRKLAND, J. M. (2014), Corporation 2020: Transforming Business for Tomorrow's World. Performance Improvement, v. 53, n. 1, p. 44-46. Available: http://onlinelibrary.wiley.com/doi/10.1002/pfi.21441/abstract. Acess: 06th May, 2015. DOI: $10.1002 /$ pfi.21441.

KYLE, B. (2013) New EPA Report Shows We are Generating More E-waste But Also Recycling, 1ed. Electronics Take Back Coalition. Available: http://www.electronictakeback.com. Acess: 01st May, 2015.

LEPAWSKY, J. (2012) Legal geographies of e-waste legislation in Canada and the US: Jurisdiction, responsibility and the taboo of production. Geoforum, v. 43, n. 6, p. 1194-1206.

LIFSET, R.; LINDHQVIST, T. (2008) Producer responsibility at a turning point? Journal of Industrial Ecology, v. 12, n. 2, p. 144.

MARCHI, C. M. D. F. (2011) Cenário mundial dos resíduos sólidos e o comportamento corporativo brasileiro frente à logística reversa. Perspectivas em Gestão \& Conhecimento, v. 1, n. 2, p. 118-135.

OELSCHLAEGER, M. (2014) Deep Ecology and the Future of the Wild in the Anthropocene. Trumpeter, v. 30, n. 2, p. 231-246.

ONGONDO, F. O.; WILLIAMS, I. D.; CHERRETT, T. J. (2011) How are WEEE doing? A global review of the management of electrical and electronic wastes. Waste management, v. 31, n. 4, p. 714-730.

ORSATO, R. J. (2009) Sustainbility Strategies. When does it pay to be green?, 1ed. New York, NY: Palgrave Macmillan.

PERERA, A.; DEL PINO, S. P.; OLIVEIRA, B. (2004) Aligning Profit and Environmental Sustainability: Stories from Industry. Washington, DC: World Resources Institute. Available: http://www.wri.org/publication/aligning-profit-andenvironmental-sustainability. Acess: 25th February, 2014.

PRZYCHODZEN, J.; PRZYCHODZEN, W. (2013) Corporate sustainability and shareholder wealth. Journal of Environmental Planning and Management, v. 56, n. 4, p. 474-493.

QU, Y. et al. (2013) A review of developing an e-wastes collection system in Dalian, China. Journal of Cleaner Production, v. 52, n.1, p. 176-184.

ROMEIRO, A. R. (2012) Desenvolvimento sustentável: uma perspectiva econômicoecológica. Estudos avançados, v. 26, n. 74, p. 65-92.

ROWLEY, H. V. et al. (2012) Aggregating sustainability indicators: beyond the weighted sum. Journal of Environmental Management, v. 111, n. 1, p. 24-33. Available: http://www.sciencedirect.com/science/article/pii/S0301479712002617. Acess: 07th May, 2015. DOI:10.1016/j.jenvman.2012.05.004.

RUTHERFORD, J. (2008) Wellbeing, economic growth and recession: Thinkpiece for the SDC workshop Living Well - Within limits. London: Sustainable Development Commission. Available: www.sdcommission.org.uk/pages/redefiningprosperity.html. Acess: 05th May, 2015.

TOWNSEND, T. G. (2011) Environmental issues and management strategies for waste electronic and electrical equipment. Journal of the Air \& Waste Management Association, v. 61, n. 6, p. 587-610. 
UNEP. (2011) Greening the Economy: Pathways to Sustainable Development and Poverty Erradication. 1ed. United Nations Environmental Program Report.

WAGNER, T. (2009) Shared responsibility for managing electronic waste: A case study of Maine, USA. Waste Management, v. 29, n.12, p. 3014-3021. Available: http://www.sciencedirect.com/science/article/pii/S0956053X09002256. Acess: 29th April, 2015. DOI: 10.1016/j.wasman.2009.06.015.

WANG, Feng et al. (2013) E-waste in China-a country report. 1 ed. Bonn, Germany: StEP Initiative.

YOUSEFPOUR, N.; BARRAKET, J.; FURNEAUX, C. W. (2012) A baseline Study of Australia's community recycling enterprises (CRE), 1 ed. Australia: Community Recycling Network Australia website. 